\title{
PROTECTION OF CONSTITUTIONAL CULTURAL RIGHTS AND FREEDOMS OF CITIZENS BY THE CONSTITUTIONAL COURT OF UKRAINE
}

\author{
Mykola Inshyn', Yurii Miroshnychenko², Yurii Paida
}

\begin{abstract}
The aim of the article is to explore the place and role of the Constitutional Court of Ukraine in the mechanism of constitutional cultural rights and freedoms protection within the context of Ukrainian constitutional justice reforming. The subject of research is the protection of constitutional cultural rights and freedoms of citizens by the Constitutional Court of Ukraine. Methodology. Scientific research is based on the use of philosophical, general, and special scientific methods and techniques of scientific cognition. The dialectic method allows examining the phenomenon of protection of constitutional cultural rights and freedoms of citizens by the Constitutional Court of Ukraine within the dynamics of its evolution and interaction with other legal concepts. The systemic method made it possible to present the mechanism of protection of constitutional cultural rights and freedoms of citizens as a combination of interrelated elements. The formal-legal method was used to analyse the regulatory framework of protection of constitutional cultural rights and freedoms of citizens by the Constitutional Court of Ukraine along with relevant decisions of this judicial body. Results obtained upon completion of the research give an opportunity to claim that the protection of constitutional cultural rights and freedoms of citizens by the Constitutional Court of Ukraine may be performed on the basis of both direct and indirect access of persons to the constitutional jurisdiction body through the regulatory compliance assessment (constitutional recourse and initiation of legal action by certain state power bodies and its officials through constitutional claim filing). Practical outcomes. Research provides: examination of doctrinal and applicable aspects of the Constitutional Court of Ukraine activity on the protection of constitutional rights and freedoms of citizens; characteristics of general theoretical essence of constitutional cultural rights and freedoms of citizens with distinguished types; analysis of peculiarities of protection of constitutional cultural rights and freedoms of citizens by the Constitutional Court of Ukraine in the course of its powers exercising. Value/originality. On the basis of a comprehensive study of constitutional doctrine, Ukrainian legislation and implementation practices certain proposals are elaborated regarding the improvement of the effectiveness of the Constitutional Court of Ukraine activity in the area of protection of constitutional cultural rights and freedoms of citizens.
\end{abstract}

Key words: constitutional justice, Constitutional Court of Ukraine, constitutional rights and freedoms of citizens, mechanism of protection of constitutional rights and freedoms of citizens, constitutional cultural rights and freedoms of citizens, protection of constitutional cultural rights and freedoms of citizens by Constitutional Court of Ukraine.

\section{JEL Classification: K2, K13}

\section{Introduction}

Processes of the Ukrainian state and society democratization and Ukraine's transformation into a law-governed and socially-oriented country require improvement of current and establishment of new mechanisms aimed at the adaptation of progressive ideas in the area of protection of constitutional rights and freedoms of citizens along with constructive, efficient relations between individuals and state power bodies.
Citizens' rights and freedoms are one of the essential indicators of current civilization. Modern condition of state and legislative development process sets a task for the legal science to carry out a comprehensive analysis of key concerns related to organization and activities of the Constitutional Court of Ukraine (hereinafter referred to as "CCU" or "the Court") as a specialized subject established to protect constitutional rights and freedoms of citizens (Bryn, 2010), including the cultural ones.

\footnotetext{
Corresponding author:

${ }^{1}$ Taras Shevchenko National University of Kyiv, Ukraine.

${ }^{2}$ Volodymyr the Great Educational and Scientific Institute of Law, Ukraine.

${ }^{3}$ Kharkiv National University of Internal Affairs, Ukraine.
} 
Constitutional rights and freedoms of citizens are one of the most important elements of the social and political system presented as the standard in the course of society's achievements evaluation, an indicator of its development level. Through this element, all individuals are involved in obtaining the material and spiritual benefits, government institutions, legal forms of willingness and private interests' realization. Quality of constitutional rights and freedoms enforcement defines the level of individual's development, his/her life and health, honour and dignity, inviolability and safety (Matskevych, 2012). Of the utmost importance in the system of essential rights and freedoms of Ukrainian citizens are the cultural rights and freedoms, which is determined with its essence, content, and specific enforcement mechanism. For Ukraine, the key problem itself is the proper enforcement of constitutional rights and freedoms of citizens that starts with the establishment of relevant state mechanisms for its protection - therefore, it is defined as exceptional for the state legal system of which is undergoing the process of transformation (Kravchenko, 2011).

After the CCU had been established, many different approaches and visions of content and activity character, procedures of constitutional justice body formation, its role and scope of authority in the area of citizens' constitutional rights and freedoms enforcement were presented by the scholars. Modern legal science still hasn't studied the problems of CCU functioning as the subject of constitutional cultural rights and freedoms protection in full scope. Lack of legal traditions and slow process of civic society establishment, low level of citizens' legal literacy and failure to accept the principle of state power distribution in practice resulted in a poor understanding of the CCU functional purpose by both society and government. The powerful protective potential of the latter is still underrated mainly over the lack of reinterpretation and realization of its capacity, functional purpose, forms and methods of influence on enforcement of constitutional cultural rights and freedoms of citizens (Bryn, 2010).

\section{The objective of the article}

In connection with this, of the utmost importance has become the study of the CCU's place and role in the mechanism of protection of constitutional cultural rights and freedoms of citizens in the context of Ukrainian constitutional justice reforming, which presents the objective of this article. Its successful achievement stipulates accomplishment of the following tasks: firstly, study doctrinal and applicable aspects of the CCU activity related to constitutional rights and freedom protection; secondly, characterize the theoretical background of constitutional cultural rights and freedoms of citizens and distinguish its types; thirdly, analyse the peculiarities of protection of constitutional cultural rights and freedoms of citizens by the CCU in the process of its powers execution.

Analysis of recent search and publications. Multiple aspects of protection of constitutional cultural rights and freedoms were studied by Ukrainian scholars including T. Bryn, S. Holovatyi, A. Holovin, M. Koziubra, O. Kravchenko, O. Martseliak, V. Radzievska, A. Selivanov, A. Tkachuk et al.

\section{Core material presentation}

Protection of citizens' rights and freedoms is ensured in the law-governed state with the help of a system of procedures, mechanisms, and institutions aimed are enforcing the individual rights on the basis of constitutional law and order. These procedures, mechanisms, andinstitutions possess certain dynamics, which is shaped by the perpetual transformation of the social environment. The proper level of protection of rights and freedoms of citizens is traditionally ensured with the written constitution presented as a basis for state power excesses limitation and protection of individual as the highest social value. One of the key achievements of Ukrainian constitutional jurisdiction and its main task is to protect the rights and freedoms of citizens. The CCU acts are aimed to ensure that the rule of law principle is observed in the course of interpretation of the Constitution's provisions related to prioritization of citizens' rights and freedoms by the state. The CCU decisions, conclusions, and rulings are the forms presenting its acts, which protect citizens rights and freedoms, established and guaranteed by the Constitution therefore, the abovementioned protection of rights and freedoms may be characterized as superior as they are not a subject to anyone's appeals, conclusive due to independence of the Court's will based on the Constitution's provisions (Selivanov, 2005).

According to O. Martseliak, constitutional-legal mechanism of Ukrainian citizens' rights and freedoms protection is presented as a system of fundamental rights and freedoms of citizens, its guarantees, state power bodies, local self-governance, and other institutions ensuring enforcement and protection of citizens' rights and freedoms, which is fixed in the Constitution (constitutional laws), unified and regulated internally (Martseliak, 1997). V. Radzievska notes that the legal mechanism of citizens' rights and freedoms enforcement is a complex multicomponent system of institutes, means, and techniques, the functional unity of which is aimed at the enforcement and protection of citizens' rights and freedoms (in case of actual violation or any threat of being violated). Its structure is composed of two subsystems - regulatory and institutional, which are interrelated and constantly interacting. Internal cohesion of all elements of these subsystems, its constructive orientation at citizens' 
rights and freedoms protection is a condition of the mechanism's effectiveness. Regulatory component of the citizens' rights and freedoms protection mechanism is presented as a set of legal rules fixed in legislative acts of the state (as laws). It is taken as a background and objectivizes the legal environment conditions to enforce the citizens' rights and freedoms. In its background are the constitutional-legal rules establishing the constitutional rights and freedoms with its guarantees, it also comprises rules defining the legal status of subjects authorized with certain powers related to citizens' rights and freedoms enforcement along with legal means and relevant conditions. In its systemic unity, these rules define the general constitutional legal order in the area of citizens' rights and freedoms protection and enforcement (Radzievska, 2013). Institutional component of the legal mechanism of citizens' rights and freedoms enforcement comprises the system of state power bodies, other authorized subjects, which ensure establishment, enforcement, protection of citizens' rights and freedoms within the scope of their authority and according to the law (Radzievska, 2013).

Constitutional control is one of the essential components of the mechanism of constitutional protection of rights and freedoms in the most developed states - a special role is given to judicial constitutional control. According to the historical background and legal traditions of different countries different models of constitutional control were formulated - American (traditional), French, European, and Amparo remedy. Ukraine has established the European model of constitutional control, which stipulates that centralized control is carried out by the specialized body of constitutional jurisdiction (Tkachuk, 2012). The key task of the CCU is to guarantee the primacy of the Constitution by exercising the delegated powers. When settling the constitutional disputes within the CCU scope of competence, it ensures the enforcement of constitutional provisions, guarantees the protection of citizens' rights and freedoms. Establishment of the CCU itself had been an important step in the strengthening of the constitutional basis of our state and law, effective protection of citizens' rights and freedoms, modification of the Ukrainian Constitution into a practically applicable legislative act.

The constitutional-legal content of the CCU activity related to enforcement of citizens' rights and freedoms is revealed through the state key obligation fixed in Article 3 of the Constitution of Ukraine - a function of constitutional order guaranteeing on the basis of prioritization of citizens' rights and freedoms. The function of the Constitution superiority guaranteeing creates preconditions for the exceptional placement of the CCU within the state mechanism of citizens' rights and freedoms protection - this condition explains the peculiarities of its legal status as a state constitutional jurisdiction body (Radzievska, 2013).
According to the opinion of O. Kravchenko, the CCU protection of citizens' rights and freedoms comprises activity performed by means of settling disputes related to constitutionality of laws, other legislative and regulatory acts issued by state power bodies, interpretation of constitutional provisions resulting in its cancellation upon condition of their inconsistency with the Constitution and restoration of rights and freedoms guaranteed by it or clarification of the legislator's opinion expressed through the norms subject to interpretation - it promotes the proper enforcement procedures initiation (Kravchenko, 2011). Protection of citizens' constitutional rights and freedoms is a basic area of the CCU activity performed literally in the course of each case consideration both directly and indirectly.

In general, when cases related to protection of citizens' constitutional rights and freedoms are being considered by the CCU, its decisions are based on the concept that all legal opinions must facilitate the enhancement of constitutional system and guarantee the axiological understanding of individual rights and freedoms. Due to the fact that state and individual interests and obligations are of different nature, objective and subjective components $\mathrm{f}$ core rights may not coincide. Constitution of Ukraine is oriented at social interests and citizens' rights and freedoms as the top priority therefore, establishing it; constitutional justice is tasked to detect this sense when we speak about the settlement of disputes on right or official interpretation of legal norm (Constitutional justice).

Having analysed the powers and practice of the CCU activity, we may claim that each format of a relevant legal action, stipulated by the Law of Ukraine "On Constitutional Court of Ukraine" dd. July 13, 2017, may refer to the protection of constitutional rights and freedoms. Subjects of all CCU legal actions within the scope of their authority take part in the implementation of the mechanism of citizens' rights and freedoms protection. Legal protection of subjects of constitutional legal actions within the mechanism of fundamental citizens' rights and freedoms, primarily related to analysis and inspection of legislative acts' constitutionality, is presented in the form of performance of obligation on ensuring enjoyment of citizens' rights and freedoms and gains characteristics of specific form of access to constitutional jurisdiction body granted to individuals. In its turn, a constitutional complaint is a form of direct reference of individual or legal entity (except legal entities in public law area) to the CCU in regard to relevant constitutional rights and freedoms protection.

Also, the official interpretation of the Constitution is an effective method of ensuring full enjoyment of constitutional rights and freedoms by the citizens. Due to this method of interpretation, content and essence of constitutional rights and freedoms are identified along with relevant scope and guarantees. 
Interpretation of provisions related to rights and freedoms gives an opportunity to harmonize its content with modern requirements. Results of official interpretation are mandatory for all legal subjects and present a ground for the restoration of violated rights and freedoms (Tkachuk, 2012).

Constitutional rights and freedoms of citizens as a legal category present a comprehensive and harmonized system, which regulates all crucial areas of social life: personal (private), political, social, economic, cultural etc. (Shemshuchenko, Karpachova, Kostetska et al., 2008). Constitutional provisions establishing citizens' rights and freedoms are based on its system defined by the constitutional law theory. Cultural rights comprise an integral part of citizens' constitutional rights and freedoms system.

The specialized literature identifies cultural rights as a group of aimed at meeting the cultural and spiritual needs of individuals (Legal encyclopedia). According to the opinion of S. Lysenkov, cultural rights are the system of constitutional citizens' rights and freedoms aimed at ensuring development and fulfilment of their intellectual demands, skills, talents, and participation in society's spiritual life (Lysenkov, 1995). Thus, T. Kostetska interprets cultural rights and freedoms as an opportunity to maintain and develop the national uniqueness of individual, access to spiritual heritage of his/her ancestors and all the mankind, their adoption and application, participation in research activities (right to education including education in native language, freedom of involvement in research, technical or creative activity etc.) (Shemshuchenko, Karpachova, Kostetska et al., 2008). A comprehensive study of legal nature of constitutional cultural citizens' rights and freedoms carried out by M. Matskevych justifies his opinion that this is a separate group of individual rights and freedoms, which deserves to be separated from the group of social and economic rights and freedoms (Matskevych, 2012). He considers constitutional cultural citizens' rights and freedoms as certain limits defining the person's behaviour fixed in the constitution and aimed at the achievement of certain social benefit in the area of cultural relations along with capacity to behave in proper way, demand equal behaviour from other subjects and request protection of the abovementioned rights and freedoms from competent state and other authorized power bodies (including the CCU) and its officials (Matskevych, 2012).

Constitutional cultural citizens' rights and freedoms include: 1) right to education (part 1 of Article 53 of the Constitution); 2) right to access to full and free preschool, secondary, vocational, and higher education in state educational establishments (part 2 of Article 53 of the Constitution); 3) right of students to state fellowships and allowances (part 3 of Article 53 of the Constitution); 4) right to free education in state educational establishments on competitive basis (part
4 of Article 53 of the Constitution); 5) right of citizens representing national minorities to enjoy their right to education in native language or attend native language course in state educational establishments or national cultural unions (part 5 of Article 53 of the Constitution); 6) freedom of literary, creative, research and technical activity (part 1 of Article 54 of the Constitution); 7) right of every Ukrainian citizen to use results of one's intellectual or creative work (part 2 of Article 54 of the Constitution); 8) right to possess, use, and dispose of one's property, results of one's intellectual or creative work (part 1 of Article 41 of the Constitution) (Matskevych, 2012). Citizens' rights and freedoms, established by the Constitution (including cultural), are harmonized with relevant provisions of international legislative acts regulating the human rights issues (Golovin, 2011). Enjoyment of constitutional cultural citizens' rights and freedoms in Ukraine promotes spiritual development of individual and formation of national ideology as a social phenomenon.

The CCU activity is of crucial importance for the development of a national system of constitutional cultural citizens' rights and freedoms and relevant legal guarantees. Thus, the CCU defines education as one of the priority areas of society's economic, spiritual, and cultural development. Right to education is right of individual to obtain certain skills, knowledge and evolve professionally to ensure sustainability and security on a national level (the CCU Decree № 5-рп/2004 dd. March 4, 2004) (Golovin, 2017). In this context, the CCU confirmed that, according to the content of applicable Ukrainian law on education, full secondary education is delivered first of all with the use of textbooks as a key means of accomplishment of tasks set for relevant educational establishments. Effectiveness, in this case, depends on the provision of access to school textbooks - its absence may be critical in terms of quality evaluation. Therefore, school textbook is a conventional, integrating or coordinating tool used by students to obtain knowledge. Provision of free textbooks to students by the state is a guarantee of secondary education accessibility. Free use of textbooks is one of the state guarantees for obtaining a full secondary education (the CCU Decree № 18-рп/2002 dd. November 21, 2002 in a case initiated by legal action (47 People's Deputies of Ukraine) regarding the compliance of Decrees of the Cabinet of Ministers of Ukraine "On Establishment of Fees for Use of Textbooks in Secondary Schools", "On Amendments to Decree of the Cabinet of Ministers of Ukraine № 1031 dd. August 31, 1996" and par. 5 of Decree of the Cabinet of Ministers of Ukraine "On Cancellation of Decree of the Cabinet of Ministers of Ukraine № 1128 dd. July 22, 1998” to constitutional provisions).

The CCU Decree № 5-рп/2004 dd. March 4, 2004 (legal action initiated by 50 People's Deputies of Ukraine on official interpretation of part 3 of Article 53 of 
the Constitution), states that "state ensures access to free pre-school, secondary, vocational, and higher education in state educational establishments" - court explained that accessibility of education is itself a constitutional guarantee of enjoying the right to education on the basis of equality principles defined by Article 24 of the Constitution, so no individual is to become a subject of refusal to enjoy his/her right to education with state obligation to provide opportunities for the enjoyment of certain rights. Free education is also fixed as a constitutional guarantee it means that individuals are provided with educational services in state educational establishments without any fixed fees established in any format (within the scope defined by part 3 of Article 53 of the Constitution). According to parts 2 and 3 of Article 53 of the Constitution, full secondary education is mandatory and free - it means all related expense are covered from the state budget. Free education stipulates that citizens are entitled to receive relevant services according to established standards without any fees paid and on a competitive basis (part 4 of Article 53 of the Constitution within the scope of delivering educational services to citizens (state order) (Selivanov, 2005; Constitutional justice). All of the above mentioned CCU legal opinions were presented in the applicable Law of Ukraine "On Education" on September 5, 2017 (The Law of Ukraine «On education»).

In order to ensure freedom of literary, creative, research and technical activity, the CCU (Decree № 9-рп/2001) ruled as unconstitutional the provisions of paragraph 2 on research activity seniority (starting from the date of academic degrees/ranks awarding) of the Decree of Cabinet of Ministers of Ukraine "On List of positions taken by research staff of state research institutions, organizations and positions taken by research and teaching staff of state higher educational establishment (III-IV accreditation level) with right to receive pension and cash allowances during retirement according to the Law of Ukraine "On Research and Technical Activity" № 923 dd. May 27, 1999 (Selivanov, 2005).

Functions of preventive and sequent control performed by the CCU are itself an important component of the system of state measures aimed at guaranteeing the enjoyment of citizens' cultural rights and freedoms. In one hand, such an activity of the CCU allows to prevent potential violations of these rights and on the other hand - improve the Ukrainian legislative system by de-facto eliminating laws and other regulatory acts or its separate provisions, which failed to regulate relevant relations including the area of protection of citizens' cultural rights and freedoms (Golovin, 2011). In this context, T. Bryn justifies the statement that constitutional control over ensuring and protection of constitutional cultural rights and freedoms simultaneously provides the "updating" impact on civil society and formation of lawgoverned state (Bryn, 2010).

\section{Conclusions}

Therefore, taking the abovementioned into account, we may state that the CCU is an important element of the mechanism of constitutional cultural rights and freedoms protection. Recognition of the latter as essential and natural along with ensuring of its enjoyment is not only a requirement of modern Ukrainian constitutionalism but its key principle. The CCU powers, established by applicable Constitution and the Law of Ukraine "On Constitutional Court of Ukraine", allow protecting constitutional cultural rights and freedoms of citizens in full scope through relevant legal actions.

Protection of constitutional cultural rights and freedoms of citizens by the CCU may be carried out on the grounds of direct and indirect access of individuals (citizens) to constitutional jurisdiction bodies through the regulatory control over the legal actions initiated by state power bodies and its officials (constitutional complaints related to the establishment of legislative acts' compliance with constitutional provisions). Full scope of protection of constitutional cultural rights and freedoms of citizens is promoted by relevant powers delegated to the CCU - preliminary and sequent control; it ensures full enjoyment of relevant constitutional cultural rights and freedoms by citizens during the process of the Constitution amending and ratification of international agreements along with protection of these rights and freedoms from any limitations or its content narrowing during the adoption of new legislation or presentation of amendments to applicable ones. The official interpretation of the Constitution is an important element of ensuring the protection of constitutional cultural rights and freedoms.

\section{References:}

Bryn, T. (2010). The Constitutional Court of Ukraine as a component in the mechanism of citizens' rights and freedoms protection: extended abstract of PhD in Law thesis: specialty 12.00 .02 «Constitutional Law; Municipal Law». Kharkiv, 19 p.

Matskevych, M. (2012). Constitutional-legal background of citizens' cultural rights and freedoms protection in Ukraine: [monograph]. Ivano-Frankivsk: Misto NV, 464 p.

Kravchenko, O. (2011). Protection of citizens' rights and freedoms by the Constitutional Court of Ukraine: doctrinal, applicable and comparative aspects: extended abstract of PhD in Law thesis: specialty $12.00 .02 \ll$ Constitutional Law; Municipal Law». Kyiv, 16 p.

Selivanov, A. (2005). Citizens' rights and freedoms protected by the Constitutional Court of Ukraine: Legal stances of modern constitutional justice doctrine. Kyiv: Logos, $104 \mathrm{p}$. 
Martseliak, O. (1997). Controlling and monitoring agencies in constitutional-legal mechanism of protection of citizens' fundamental rights and freedoms in Ukraine: extended abstract of PhD in Law thesis: specialty 12.00.02 «Constitutional Law; Municipal Law». Kharkiv, 22 p.

Radzievska, V. (2013). Constitutional Court of Ukraine as a component of the mechanism of protection of citizens' fundamental rights and freedoms: extended abstract of PhD in Law thesis: specialty $12.00 .02 \ll$ Constitutional Law; Municipal Law». Kyiv, 16 p.

Tkachuk, A. (2012). Constitutional Court of Ukraine as a component of the mechanism of protection of citizens' fundamental rights and freedoms: model approach : extended abstract of PhD in Law thesis: specialty 12.00.02 $\ll$ Constitutional Law; Municipal Law». Kyiv, 20 p.

Constitutional justice in protection of citizens' fundamental rights and freedoms and settlement of disputes on the power subjects' competence: analytical report (2008). Kyiv. Verkhovna Rada Publishing House, 96 p.

The Law of Ukraine «On Constitutional Court of Ukraine» № 2136-VIII dd. July 13, 2017. Retrieved from: http://zakon.rada.gov.ua/laws/show/2136-19

Shemshuchenko, Y., Karpachova, N., Kostetska, T. et al. (2008). Constitutional rights, freedoms and obligations of citizens in Ukraine: [monograph]. Kyiv: Yurydychna dumka, 252 p.

Legal encyclopedia: in 6 vol. Under the editorship of Y. Shemshuchenko et al. (1998). Kyiv: Ukrainian encyclopedia, Vol. 3. 792 p.

Lysenkov, S. (1995). Social and individual value of citizens' cultural rights and freedoms. Philosophical issues of law and law enforcement activity: set of scientific works. Kyiv: Ukrainian Academy of Internal Affairs, pp. 62-66.

Golovin, A. (2011). Protection of citizens' rights and freedoms in the course of justice execution by the Constitutional Court of Ukraine: [monograph]. Kyiv: Logos, 307 p.

Golovin, A. (2017). Human rights: interpretations by the Constitutional Court of Ukraine, $2^{\text {nd }}$ edition, amended and modified. Kyiv: Logos, 399 p.

The Law of Ukraine «On education» № 2145-VIII dd. September 5, 2017. Retrieved from: http://zakon.rada.gov.ua/ laws/show/2145-19 